International Journal of Agriculture, Environment and Bioresearch

Vol. 5, No. 04; 2020

ISSN: $2456-8643$

\title{
OVARIAN RESPONSE IN BRAHMAN COWS IN POSTPARTUM ANESTRUS FED WITH ENSILED OF SORGHUM
}

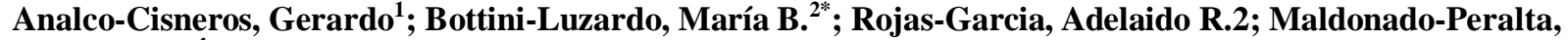
María de los Á. '; Sánchez-Santillán, Paulino²; Filiberto Magadan Olmedo² and Valenzuela-Lagarda, José L. 3 ${ }^{1}$ Maestría de Producción de Bovinos en el Trópico. ${ }^{2}$ Facultad de Medicina Veterinaria y Zootecnia N², Universidad Autónoma de Guerrero. ${ }^{3}$ Centro Regional de Educación Superior de la Costa Chica, Campus Cruz Grande, Gro.
\end{abstract}

https://doi.org/10.35410/IJAEB.2020.5537

\begin{abstract}
Objective: To evaluate the restarting of ovarian cyclicity and the pre-ovulatory follicle diameter of cows in early postpartum period fed sorghum ensiled with sowing without fertilization (T1) and fertilized (T2).
\end{abstract}

Design / Methodology / Approach: Completely randomized design. The response variables were, presence of corpus luteum (CL), as indicative of restarting ovarian activity, and subsequent development of a follicle pre -ovulatory for both revisions ultrasound scanning was used. The data obtained was analyzed with PROC GLM of SAS (SAS, 2011) the measures were compared with the Tukey test $(\alpha=0.05)$.

Results: In the 23 cows fed sorghum ensiled with fertilized sowing(T2) CL and pre - ovulatory follicle were observed. In the case of T1, only 12 cows developed corpus luteum and preovulatory follicle. The diameter measure of the follicles of the cows in (T2) was $18.1 \mathrm{~mm}$, while T1 was $0.78 \mathrm{~mm}$.

Study limitations/implications: With the results observed in the present study, it can be inferred that the management of the crop, in this case the crop of sorghum, has effects on the ovarian reactivation of Brahman cows in the early postpartum period, which implies that the producer you must take care of the feeding of the cattle, from the moment of sowing until it reaches the mouth of animal.

Findings/conclusions: According to the results, it is concluded that feeding with ensiled of fertilized sorghum during sowing to cows in the early postpartum period could favor the restart of the estrous cycle and increase the diameter of the follicles.

Keywords: ovaries, corpus luteum, prostaglandins F2a, pre-ovulatory follicle, ultrasound scanning.

\section{INTRODUCTION}

Reproduction is a fundamental pillar of the livestock production system, depending, to a large degree, the productivity and rentability of bovine husbandry companies of the physiological 
capacity of females to meet the goal of having one calf per year (Meléndez and Bartolomé, 2017).

One of the problems faced by beef cattle producers is the postpartum anestrus, period after delivery during which there is not estrous(Báez and Grajales, 2009).A determining factor to reduce to the maximum the period of postpartum anestrus is a proper nutritional management (Motta-Delgado et al., 2011).

In the tropics, the most used production system is the extensive, (Pérez et al., 2001; Henao and González, 2008; Vásquez - Cano and Olivera-A, 2010; Franco andUribe, 2012), characterized in the reproductive field by low fertility of the cow due to poor nutritional level, especially in the dry season when paddocks decrease forage production (Osorio-Arce and Segura-Correa, 2010). An alternative in dry periods, is feeding with ensiled,since it is possible to offer quality food to animals. (Salcedo, 2007; Bolaños et al., 2012; Fernández-Paredes et al., 2017). In this respect the ensiled of sorghum is presented as an alternative due to the adaptation of the plant to tropical conditions(Ribeiro et al., 2007; Carrasco et al., 2011; Fernández et al., 2013).

The application of feeding strategies can contribute to the activation of ovarian follicular dynamics,as revealed by transrectalultrasonography observations, showing that nutritional factors, management and season are related to the dynamics of follicular growth and the restart of the estrous cycle (Dominguez et al., 2007; Gutiérrez-Lizarazo and Báez-Sandoval, 2014), being growth follicular an important aspect, due the size of it could be related with the percentage of gestation (Gonzalez, 2017), being more likely that with a larger diameter follicle increase the probability that a gestation will be established, than when there is a smaller follicle (Guzmán, 2018) .

Exist little investigation about the effect that the consumption of ensiled could have,from fertilized sowing on the ovarian dynamics of cows in early postpartum, so that the objective of this investigation is to evaluate the restart of ovarian cyclicity

and the diameter of the pre-ovulatory follicle of cows in early postpartum period fed with ensiled of sorghum with and without fertilization.

\section{MATERIALS AND METHODS}

\section{Location}

The field investigation was carried out from March $1^{\text {st }}$ to May $30^{\text {th }}, 2019$ at Rancho los Laureles located at the coordinates Latitude: 16.4666, Longitude: -98.4166 $16^{\circ} 27^{\prime} 60^{\prime \prime}$ North, 98 $24^{\prime} 60^{\prime \prime}$ West, The area has an Aw climate characterized by being a dry tropic according to the KöppenGeiger system classification. Climate data was obtained from the CONAGUA agrometeorological station located in the municipality of Cuajinicuilapa.

The bromatological analysis of the ensiled of sorghum was carried out in the Animal Nutrition Laboratory of the Facultad de Medicina Veterinaria y Zootecnia $\mathrm{N}^{0} 2$ of the Universidad Autónoma de Guerrero.

\section{Characteristics of the ensiled of sorghum}


Two ensiled of sorghum were used; T1 that was made with plants from a crop that was applied with 18-46-00 diammonium phosphate fertilizer, ammonium sulfate and urea, and T2 that was made with plants that came from a crop that did not receive any type of fertilization. Both ensiled were left to ferment for three months. Later, bromatological analyzes were performed, in the Animal Nutrition laboratory, determining dry matter (DM) and crude protein (CP), according to the methodology of AOAC (2005); neutral detergent fiber (NDF), acid detergent fiber (ADF) with the methodology described by Van Soest et al. (1991), and determination of lactic acid and pH with the methodology described by Lorenzo-Hernández et al., (2019).

Table 1 shows the nutritional quality of the ensiled of sorghum with fertilization (T1) and without fertilization (T2) at sowing.

Table 1. Bromato logical analysis of the ensiled of sorghum with fertilization (T1) and without fertilization (T2) at sowing.

\begin{tabular}{|lll|}
\hline Element & T1 (\%) & T2 (\%) \\
\hline Dry Matter (DM) & 33.60 & 47.67 \\
Crude Protein (CP) & 7.83 & 5.83 \\
NeutralDetergent Fiber & 51.06 & 43.36 \\
Acid Detergent Fiber & 28.51 & 25.21 \\
Lactic Acid & 4.51 & 2.86 \\
pH & 4.33 & 4.66 \\
\hline
\end{tabular}

\section{Selection and management of cattle}

46 multiparous Brahman breed cows were selected between 6 and 8 years of age, with 90 days postpartum, which were weaned at the start of the investigation, moment in which the evaluation of the reproductive system was carried out using a Chison Eco5®ultrasound scanner (China)with a $6.5 \mathrm{MHz}$ linear rectal transducer, verifying absence of CL.

The cows were divided randomly into two groups of 23 cows, one group was fed with ensiled of sorghum with fertilized sowing (T1), the other group was fed with ensiled of sorghum without fertilized sowing (T2).

The daily consumption of ensiled, $\mathrm{kg} \mathrm{DM} / \mathrm{cow} / \mathrm{day}$, which was adjusted to $3 \%$ of live weight (PV) Cerdas-Ramírez (2013). During the experiment, the cows were weighed monthly to perform the consumption adjustment and keep the proportionbefore mentioned (Table 2).

The cows were subjected to a period of adaptation to silage consumption for 10 days. During the period study, the cows were kept stabled with water ad libitum, offering the ensiled at 7:00 and 16:00 $\mathrm{h}$. 
Table 2. Monthly average in $\mathrm{kg}$ of dry matter (DM) of the ensiled of sorghum offered/animal/day to cows in early postpartum period.

\begin{tabular}{|lccc|}
\hline Ensiled & March & April & May \\
\hline T1 (kg DM) & $11.58^{-1}$ & $12.21^{-1}$ & $12.84^{-1}$ \\
T2 (kg DM) & $11.4^{-1}$ & $11.94^{-1}$ & $12.48^{-1}$ \\
\hline
\end{tabular}

T1:ensiled made with fertilized sorghum during sowing, T2: ensiled made with unfertilized sorghum during sowing.

\section{Body condition (CC).}

The initial body condition (CC) was evaluated at the beginning and at the end of the study period, using the methodology described by Wildman et al., (1982) with a scale of 1 to 5 points, with increments of 0.25 points, where 1 is a starving cow and 5 is obese. At the beginning of the experiment, the cows in both groups exhibited a $\mathrm{CC}$ of $1 \pm 0.5$ points.

\section{Ovarian response}

On day 75 of treatment, ultrasound scanning examination was performed to verify the ovarian condition, presence of corpus luteum.

To homogenize the observation time of the pre-ovulatory follicle, cows with presence of corpus luteum were applied $5 \mathrm{ml}$ of prostaglandins $\mathrm{F}_{2 \alpha}\left(\mathrm{PGF}_{2 \alpha}\right)$ (Lutalyse/Zoetis $\left.{ }^{\circledR}\right)$ (D'Enjoy et al., 2012), whose first dose was applied on day 75 of treatment and the second dose was applied on day 87. Subsequently, on day 90 the presence of the pre-ovulatory follicle was determined,considering as pre-ovulatory follicle the one that had with a minimum diameter of $7.3 \mathrm{~mm}($ Henao, 2010). To measure the pre-ovulatory follicle, the vertical and horizontal axis of the follicle was measured (Corredor and Páez, 2012) .

Experimental design and statistical analysis: A completely randomized design was used,the evaluated variables were presence of corpus luteum and pre-ovulatory follicle, the data obtained were analyzed with PROC GLM of SAS (SAS, 2011)means were compared with Tukey's test ( $\alpha$ $=0.05$ ).

\section{RESULTS AND DISCUSSION}

The CC was similar in both groups, $3.5 \pm 0.5$ points, so it can be inferred that had not effect on the results of ovarian variables evaluated. The results of CL presence and pre-ovulatory follicle size in postpartum Brahman cows are seen in Table 3. 
Lanuza, (2010) and Tovío-Luna and Duica-Amaya (2012) affirm that nutrition plays an important role in reproduction, energy being an extremely important element during the early postpartum period, so that reactivation can occur of ovarian activity. The CC indicates that in both groups the level of thickening was similar and therefore there would be not difference in the energy available for the reactivation of ovarian cyclicity and follicular growth.

However, all the T1 cows presented corpus luteum on day 75 of the study, while 12 cows of group T2 presented corpus luteum. In this same sense, the size of the pre-ovulatory follicle of the T1 cows was bigger than T2, finding statistical differences between groups (Table 3) for both variables.

These results suggest that feeding with ensiled fertilized sorghum during sowing contributed to the restart of ovarian cyclicity and follicle growth.

Motta-Delgado et al., (2011) relates the energy balance, the maximum diameter reached by the dominant follicle, the period calving-first ovulation and corpus luteum first, with the amount of ingested nutrients in the ensiled.

The differences between treatments, in terms of the reactivation of ovarian cyclicity and the size of the pre-ovulatory follicle, could be explained could be explained by it pointed out by Garcés et al., (2004) who indicate that the energy released in the fermentation of glucose to lactic acid is preserved by phosphorylations at the substrate level in the form of highenergy phosphate bonds. In this sense, the lactic acid level of the ensiled was higher in T1 (Table 1), so it could be inferred that the cows consuming this ensiled had more energy than they could have used for follicular growth and formation of a CL.

The differences are more evidents when comparing the results obtained with those reported in grazing Brahman cows, where the pre-ovulatory follicles ranged from $6.8 \mathrm{~mm}$ to 11.2mm (Henao, 2010). Similar results are reported by García-Bracho et al., (2015) and Ayala et al., (2017).

Table 3. Number of cows with corpus luteum and pre-ovulatory follicle size (mm) of Brahman cows in postpartum anestrus fed with ensiled of sorghum of fertilized sowing (T1) and ofsowing of sorghum without fertilize (T2).

\begin{tabular}{|lccc|}
\hline & T1 & T2 & SEM \\
\hline Final Body Condition & 3.45 & 3.22 & 0.02 \\
$\begin{array}{l}\text { Number of cows with corpus } \\
\text { luteum }\end{array}$ & $26^{\mathrm{b}}$ & $12^{\mathrm{a}}$ & 0.06 \\
$\begin{array}{l}\text { Fol. } \\
\text { Size Preovulatory }(\mathbf{m m})\end{array}$ & $18.1^{\mathrm{b}}$ & $7.8^{\mathrm{a}}$ & 0.12 \\
\hline
\end{tabular}


$\mathbf{a b}$,means with different letters indicate that there are statistical differences ( $p>0.05$ ). T1; cows fed with ensiled of sorghum of fertilized sowing, T2; cows fed with ensiled ofsowing of sorghumnon fertilized.

\section{CONCLUSION}

To feed with ensiled of fertilized sorghum duringsowing, to cows in the early postpartum period, could favor the restart of the estrous cycle and increase the diameter of the preovulatory follicles.

\section{REFERENCE}

Ayala, G. L. E., Pesántez, P. J. L., Rodas, C. E. R., Méndez, Á. M. S., Soria, P. M. E., Torres, I. C. S., Váquez, M. J. M., \& Pesántez, C. E. del R. (2017). Tamaño del folículo ovulatorio, cuerpo lúteo y progesterona sanguínea en vaquillas receptoras de embriones de tres razas en pastoreo en Ecuador. Revista de Producción Animal, 29(2), 65-72.

Báez, S. G., \& Grajales, L. H. (2009). Anestro posparto en ganado bovino en el trópico. Revista MVZ Cordoba, 14(3), 1867-1875. https://doi.org/10.21897/rmvz.347

Bolaños, A. E. D., Claude, E. J., \& Audebert, G. (2012). Rendimiento y calidad de híbridos de sorgo con y sin nervadura café. Revista Mexicana de Ciencias Agrícolas, 2(1), 441-449. https://doi.org/10.29312/remexca.v3i3.1440

Carrasco, N., Zamora, M., \& Melin, A. (2011). Importancia del cultivo de sorgo, Descripción bótanica y escala fisiológica, tipos de sorgo, el sorgo y uso como silaje y diferido en la alimentación animal. In Manual del sorgo. http://inta.gob.ar/sites/default/files/inta_manual_de_sorgo_renglon_191.pdf

Cerdas-Ramírez, R. (2013). Formulating rations for dairy and beef cattle. Development of a practical module for technician and livestock students of Guanacaste, Costa Rica. InterSedes, XIV(29), 126-153. ISSN 2215-2458

Corredor, C. E. S., \& Páez, B. E. M. (2012). Aplicaciones de la ultrasonografía en la reproducción bovina revisión. Ciencia y Agricultura, 9(2), 29-37.

D’Enjoy, D., Cabrera, P., Vivas, I., \& Díaz, T. (2012). Dinámica Folicular ovárica Durante el ciclo estral en vacas Brahman Ovarian Follicular Dynamics During the Estrous Cycle in Brahman Cows. Revista de La Facultad de Ciencias Veterinarias, UCV, 53(1), 39-47. http://www.redalyc.org/pdf/3731/373139079005.pdf

Domínguez, C., Garmendia, J., \& Martínez, N. (2007). Influencia de la época de parto, la condición corporal y la suplementación sobre la actividad ovárica postparto de vacas mestizas bajo pastoreo mixto en el norte del estado Guárico, Venezuela. Revista de La Facutad de Ciencias Veterinarias, UCV, 48(1), 37-50.

Fernández-Paredes, M. E., Zambrano-Sarabia, S. J., Zumba-Montes, L. C., \& López-Castillos, G. (2017). Consideraciones Generales Sobre El Proceso De Elaboración De Silos. Roca. Revista Científico - Educacional de La Provincia Granma, 13(3), 107-116. http://revistas.udg.co.cu/index.php/roca/article/view/346

Fernández, M. A. E., Stuart, M. R., Chongo, B., \& Martín, M. P. C. (2013). Evaluación del valor nutritivo y los costos de producción del heno en pie y del ensilaje de sorgos nervadura marrón o BMR (Brown Middle Rib). Revista Cubana de Ciencia Agrícola, 47(2), 159-163.

Franco, J., \& Uribe, V. L. F. (2012). Hormonas reproductivas de importancia veterinaria en 
hembras domésticas rumiantes. Biosalud, 11(1), 41-56.

Garcés, M. A. M., Berrio, R. L., Ruíz, A. S., Serna, D. J. G., \& Builes, A. A. F. (2004). Bacterias Acido Lacticas En La Fementacion De Ensilaje. Revista Lasallista de Investigación, 1(1), 66-71.

García-Bracho, D., Hahn, M., Pino, D., Perea, F., \& Merlis, L. (2015). Follicle Growth and Dominant Follicle Size in Grazing Crossbred Cows. Revista Cientifica, FCV-LUZ, XXV(3), 219-222.

González, Y. (2017). Tamaño del folículo ovulatorio, volumen del cuerpo lúteo y niveles séricos de progesterona, durante el ciclo estral y gestación temprana en vacas Holstein en Bogotá. Biología y Adaptación de Los Animales Al Trópico Reproducción Animal y Salud Del Hato, 23. http://www.bdigital.unal.edu.co/59829/1/Tesis_Yulieth_Monroy_G.pdf

Gutiérrez-Lizarazo, D. E., \& Báez-Sandoval, G. M. (2014). La ultrasonografía en bovinos. Respuestas, 19(1), 99-106. https://doi.org/10.22463/0122820x.12

Guzmán, A. F. V. (2018). Efecto del diametro del foliculo preovulatorioen el momento de la IATF y de la expresion del estro sobre la tasa de preñez en vacas nelorec on cria al pie. Universidad Nacional de Córdoba, 70.

Henao, R. G. (2010). Algunos factores relacionados con la dinámica folicular en Bos indicus. Rev Fac Nac Agron, 63(2), 5577-5586.

Henao, R. G., \& González, C. V. (2008). Relationship of Live Weight and Corporal Condition Variation. Revista Facultad Nacional de Agronomía Medellín, 61(1), 4394-4399.

Lanuza, F. (2010). Requerimientos de Nutrientes Según Estado Fisiológico En Bovinos De Leche *. Instituto de Investigaciones Agropecuarias, 148, 1-16. http://biblioteca.inia.cl/medios/biblioteca/boletines/NR33837.pdf

Lorenzo-Hernández, R., Torres-Salado, N., Sánchez-Santillán, P., Herrera-Pérez, J., MayrénMendoza, F. de J., Salinas-Ríos, T., Rojas-García, A. R., \& Maldonado-Peralta, M. de los Á. (2019). Evaluation of the quality and bromatological characteristics of ensilages made with pumpkin residues (Cucurbita argyrosperma). Revista Internacional de Contaminacion Ambiental, 35(4), 957-963. https://doi.org/10.20937/RICA.2019.35.04.14

Meléndez, P., \& Bartolomé, J. (2017). Avances sobre nutrición y fertilidad en ganado lechero: Revisión. Revista Mexicana de Ciencias Pecuarias, 8(4), 407-417. http://www.scielo.org.mx/pdf/rmcp/v8n4/2448-6698-rmcp-8-04-00407.pdf

Motta-Delgado, P. A., Ramos-Cuéllar, N., González-Sánchez, C. M., \& Rojas-Castro, E. C. (2011). Follicular dynamics in the reproductive life of female livestock. Veterinaria $y$ Zootecnia, 5(2), 88-99.

Osorio-Arce, M. M., \& Segura-Correa, J. C. (2010). Efectos raciales y ambientales sobre edad al primer parto e intervalo entre partos de vacas Brahman y sus cruces en el trópico-húmedo de México. Livestock Research for Rural Development, 22(8).

Pérez, H. P., Sánchez del Real, C., \& Gallegos, S. J. (2001). Anestro postparto y alternativas de manejo del amamantamiento en vacas de doble propósito en trópico. Invest Agr.: Prod Sanid Anim, 16(2), 1-14.

Ribeiro, P. L. G., Mario, R. N., Gonçalves, C. L., \& De Assis, P. D. A. (2007). Consideraciones Sobre Ensilajes De Sorgo. Jornada Sobre Producción y Utilización de Ensilajes, 1979, 5168.

Salcedo, D. (2007). El ensilado en la alimentación del vacuno de leche. Resultados de quince 
International Journal of Agriculture, Environment and Bioresearch

Vol. 5, No. 04; 2020

ISSN: $2456-8643$

años de experiencias en Cantabria. Revista de La Sociedad Española Para El Estudio de Los Pastos, 37(1), 81-127. https://doi.org/10.13140/2.1.4068.3204

Tovío-luna, N. I., \& Duica-Amaya, A. (2012). Factores relacionados con la dinámica folicular en la hembra bovina. Spei Domus, 8(17), 38-47.

Vásquez - Cano, J. F., \& Olivera - A, M. (2010). Señalización Celular en el Folículo Antral Bovino. Orinoquia, 14(2), 178-187. https://doi.org/10.22579/20112629.80

Wildman, E. E., Jones, G. M., Wagner, P. E., Boman, R. L., Troutt, H. F., \& Lesch, T. N. (1982). A Dairy Cow Body Condition Scoring System and Its Relationship to Selected Production Characteristics. Journal of Dairy Science, 65(3), 495-501. https://doi.org/10.3168/jds.S0022-0302(82)82223-6 